\title{
The Admiral Combs Design Retreat
}

\author{
Stacy Eisenman and George List \\ Department of Civil and Environmental Engineering \\ Rensselaer Polytechnic Institute
}

\begin{abstract}
The Admiral Combs Design Retreat provides an opportunity for students to experience many aspects of civil engineering in a "real world" situation. For the past six years the retreat has offered to returning seniors, five days of irreplaceable knowledge and networking. For a week students become the guests and partners of a design firm. Throughout the retreat students engage in various projects and learn how the disciplines of civil engineering overlap and integrate with other disciplines to solve real-world problems. The firm presents a series of engineering tasks to the students. Each of the tasks represents a problem focused on one of the civil engineering concentrations. Working in teams, the students consult with the firms' field experts to recognize the complexities of the problems. They then use their theoretical knowledge to develop conceptual solutions. In addition to gains in experiential knowledge, the retreat provides an opportunity for the students to network with the firm's top engineers and more importantly with their fellow classmates. The retreat is a fully funded experience, which offers students the opportunity to better understand how their education will be put into practice. Students are not required to attend the retreat and no credit is given for attending. The reputation of the retreat has grown among the students. Each year the retreat provides students with insights into their profession and their futures. Without question the retreat instills students with a respect for their chosen profession and greatly motivates and stimulates them to pursue addition interests in their studies. This paper describes the retreat in detail, explains how the retreat has affected the lives and careers of the participants, and compares the retreat to other similar integrative experiences offered by other civil engineering programs.
\end{abstract}

\section{Introduction}

In the world of civil engineering, practicing professionals often work on large-scale projects with huge costs and impacts. Practical experiences provide an effective way to let students see how the things they learn in the class relate to the real world. Moreover, the practical experiences can be used to expose students to career options, role models, construction sites, and experience of the day-to-day challenges of project management.

Some conventional examples of such practical experiences are cooperatives education programs (co-ops) and internships. At Rensselaer Polytechnic Institute there is an ongoing search for additional opportunities to provide it students with practical experiences. The civil engineering 
program has successfully developed and implemented an annual event know as the Admiral Lewis B. Combs Memorial Design Retreat, which acts as a unique, high intensity practical experience for it undergraduates. The department is also currently working on integrating a series of "Hands on Experience" courses into the curriculum.

Many things are important to consider in devising such a practical experience. Among these are its duration, focus, team composition, supervision, and location. The success of the experience relies greatly on the intricacy of its development. The characteristics of a practical experience depend greatly on the goals that are established. The experience can be short or long (e.g., a week to a year) and narrow or broad in scope. Experiences can involve individual students, teams of students, or interactions between students and others (e.g., faculty, professionals). The environment of the experience can be at school (e.g., capstone design) or on-site (e.g., a co-op assignment). The overall challenge is create an experience, which will successfully meet its academic objectives, while providing an experience that optimizes the time and opportunities available and provides the highest value possible to the student.

The intention of this paper a review of a collection of existing approaches to providing practical experiences and to provide information of how the Admiral Lewis B. Combs Memorial Design Retreat was developed, its goals, as well as demonstrate the value of such a practical experience. In doing so the discussion will examine the structure of past retreats and the impacts they have had on their participants.

\section{$\underline{\text { Review }}$}

At the undergraduate level practical experiences appear in a variety of activities. Students are exposed to practical experiences through courses, planned events, co-ops, internships, etc. Without question, these practical experiences add significant value to the undergraduate curriculum $[3,11,27,33,36]$. This is especially true in civil engineering where so much of professional practice relates to work in the field: the planning, design, construction, operation, and refurbishment of large-scale facilities, like bridges and buildings, which are part of the built infrastructure. It is hard to appreciate what civil engineering is about without seeing full-scale facilities first-hand.

Practical experience also gives civil engineering students an opportunity to relate their classroom knowledge to the real world. Concepts like stress and strain take on more vivid meanings when they are actually demonstrated. The relationship of design to construction becomes more real as the true scope and scale of civil engineering facilities becomes apparent.

Co-ops and internships are classic practical experiences. They have been part of undergraduate engineering programs for a long time [35]. Some universities (e.g., Drexel Institute) mandate a co-op experience. Others have optional co-op programs. Still others make co-ops and internships available for those who are interested in them. Co-ops typically can last from a semester to an entire year. Internships are typically shorter, spanning a single summer.

Co-ops and internships, however, do not fit with every student's agenda. Some students have extensive field experience already (e.g., their family is in the construction business). Some 
students choose to use their free time to explore different areas of interest. Others would rather spend their breaks working on research projects (which could also provide its own practical experiences). Still others see their civil engineering degree as leading to some other, more longterm career.

Despite these caveats, quality co-op and internship experiences are important. All civil engineering programs should strive to have excellent opportunities like these for their students.

Organizing meaningful co-ops and internships requires strong partnerships between civil engineering firms and schools [30]. Moreover, the firms must be committed to providing a highquality experience for the interns. Having such partnerships should be a major objective for all civil engineering programs. Besides forging these partnerships between businesses and the university, each student's situation should be arranged with care to ensure a rewarding experience. Finding housing may be a challenge, the experience may span only part of a project, and the firm's needs may prove to be different from the student's skills [13].

In addition to co-ops and internships, students sometimes have practical experiences within their courses. Many senior design courses involve practical experience. These experiences teach teamwork, enhance problem-solving skills, promote interaction with industry professionals and expose students to the design process for a full-scale project. At Kettering University (formerly General Motors Institute), for example, the Industrial Engineering program believes that its capstone design course offers students a chance to design/redesign projects, and provides students with an opportunity to apply their coursework and other experiences in a real world environment [18].

Still other opportunities to provide students with practical experiences come in the form of clinics and other planned events. The Harvey Mudd College offers an Engineering Clinic program, where students, faculty and company liaisons work together throughout the academic on a variety of industry sponsored projects. This provides students with a closer look at the working world, and the faculty and companies with a different style of teaching [7].

Through a search for student oriented practical experiences, it was discovered that design charettes are a popular idea. In general the charettes are short retreats, lasting a day or two, which provide students with a risk-free opportunity to work as part of a team to solve a problem or complete a design. Illinois Institute of Technology offers charettes for its architecture students. This allows the students to participate in Masonry Design and tour a concrete masonry manufacturing plant [17]. Similarly North Dakota State University hosts a design charette for its architecture students. The students participate in an intensive design activity for developing design ideas for a campus site [28]. It is apparent that the majority of these opportunities are presently associated with architectural programs, but charettes (or similar events) could offer great opportunities to students in civil engineering as well. In every case, through a brief but concentrated period of instruction and practice, students could sharpen their skills through these experiences. In addition, and perhaps more importantly, since the people are in an unfamiliar setting with new challenges, they develop emotional maturity and hone their skills in teamwork and leadership. 
Civil engineering curricula used to involve at least one type of hands-on experience. Almost every civil engineering program had a surveying camp. Rensselaer's undergraduates spent more than twelve weeks over two summers learning how to create topographic maps and design rights-ofway for railroads and highways. Through these camps, students learned about the practice of civil engineering while becoming interested and acquainted with career paths they could pursue after graduation. Only a few schools in the U.S. currently offer surveying camps.

One program that resembles a modern-day surveying camp can be found at California Polytechnic State University at San Luis Obispo. In this instance, students are assigned to a project recently finished by an engineering firm [10]. They have three days to develop a preliminary design and one additional week to interpret data given to them. Although representatives from the company mentor the students on their design, the students once again do not get to see the extent of real practice that the Admiral Combs participants do. Similarly, although the students analyze a real site, they do not see the kind of technology found at places like the "Big Dig" where the Admiral Combs retreats have been held.

\section{The Admiral Combs Retreat}

As Rensselaer Polytechnic Institute's undergraduate civil engineering program was being reviewed several years ago; we sensed that there was a need for a short, high-intensity event that should be made available to all undergraduates. The goal was to combine the best features of coops and internships with the integrative nature of capstone design. The result was the Admiral Lewis B. Combs Memorial Design Retreat. (Admiral Combs was a graduate of Rensselaer, a founder of the U.S. Navy Seabees, and a long-time chairman of Rensselaer's Civil Engineering Department.) The Admiral Combs Design Retreat is an annual, one-week event that provides an opportunity for students to experience a variety of civil engineering concepts in a "real world" situation. It is not required. Students elect to attend.

The retreat occurs one week before the fall semester begins. Returning seniors that elect to participate become the guest of a design firm. The week consists of a large number of activities, which provide the students with an experience of a lifetime. These activities include meeting and working with practicing engineers, touring large construction sites, working on design tasks, and giving presentations. The event is completely financed by alumni and other sources and is has no credit associated with it. The risk free experience provides a clear picture of the profession the students are about to join.

To date, expenses have ranged from $\$ 8,000-\$ 12,000$ for groups of 8-18 students. A value of $\$ 10,000$ is used for planning. These costs are likely to be different from one realization to another. If one assumes 16 participants, with a senior faculty member, an assistant, 10 rooms, meals for 5 days, and travel for all, the expense might be $\$ 15,000-\$ 20,000$. Of course, spending more is always possible. Ways we manage to control costs include using dormitory rooms at a local university, selecting locations near school, and dovetailing the event with the beginning of school (so the trips for some participants begin at home).

The retreat is intended to achieve several goals. The main one is to provide the students with an 
opportunity to truly get to know each other, while providing them with a high quality, practiceoriented, integrative experience. The retreat is also intended to enhance teamwork skills, sharpen problem-solving skills, build friendships, visit state-of-the-art civil engineering facilities (under construction and constructed), illustrate best practice design in action, and provide interaction with professional role models.

The primary goal is not entirely academic. The event needs to provide students with an opportunity to get to know one another. Networking and interpersonal trust are critical to longterm professional success. A student's own classmate should be someone that he or she trusts most. The retreat allows students to get to know each other within the design teams, but also on a more personal level. The retreat provides students with the chance to get to know each other outside of class and work as well. Students spend free time together visiting sites, eating meals and relaxing. The increased interactions between students on the retreat tend to continue throughout the school year and produce a dynamic learning environment.

The goal of providing a high-quality practice-based experience has the added benefit of helping Rensselaer attract the very best undergraduates. It also ensures that all civil engineering undergraduates will have an opportunity to participate in a first-rate practical experience. In order to reach this goal, the retreat places students in a prestigious environment that challenges them to relate their theoretical knowledge to real-world projects.

Acting as a sub-goal: enhancement of teamwork and problem solving skills are critical to success in the industry and therefore are a key part of this event. The design tasks allow teams of students focus on a variety of design tasks related to a real-world project. Students get to practice their problem solving skills on-site of a project, under the watchful eye of practicing engineers. Teamwork is essential in developing solutions to the design tasks.

Another sub-goal is to provide students with an opportunity to see state-of-the-art civil engineering facilities, observe best practice design, and meet and interact with professionals. In order for students to grasp truly grasp the reality of the industry it is crucial that they have an opportunity to see state-of-the-art civil engineering facilities. Students have to understand where the state-of-the art lies in applying classroom knowledge to field-based problem solving if they are to be as prepared as possible for entering the professional workforce. It is only through seeing the best in the past and present that the best in the future is inspired.

To address these goals the event is held at a prestigious engineering firm, where student can work face-to-face with practicing engineers on tasks that are actually being completed. The students are briefed on past and ongoing work that the firm was/is involved with and the retreat offers students a chance to tour ongoing construction projects as well as completed projects.

\section{History of the Retreats}

The first Admiral Combs Design Retreat occurred in 1997. Fourteen seniors spent a week in the offices of KCI Technologies, Inc., in Hunt Valley, MD. Divided into three multi-disciplinary teams, these students developed preliminary designs for a major commuter rail station just south of Baltimore. It was explained to them that the State of Maryland wished to expand its Maryland 
Commuter Rail (MARC) service by constructing a new station and they were responsible for developing initial, conceptual designs for the facility. (In reality, the station had already been constructed; KCI had been responsible for the design work.) The students were given the design requirements, including details of the station's proposed site, which was located near several industrial parks and suburban population centers. Access to the proposed station was to be constructed from a new interchange connecting to a Maryland state highway. The design decisions of the final construction were concealed from the students until their projects were complete.

The students first became familiar with the baseline maps for the site and began determining a preliminary layout. They made decisions about parking facilities, bus stops, the station building, platforms, detention ponds, and a freeway interchange. They also designed plans to protect the wetlands and a "specimen tree".

As ideas emerged, the students engaged in question-and-answer sessions with various KCI engineers. The teams sought guidance about difficult design decisions. They asked about things such as the environmental requirements that had to be met, expectations for parking, pedestrian circulation, waiting room space, etc. More design iterations ensued as the students worked toward a final set of conceptual plans.

At the end of the week, the students presented their designs to the KCI engineers who had mentored them throughout the week. All aspects of the site's development were addressed. One aspect was the design of the interchange from the surrounding state highway onto the site's access road, including a large bridge to carry the state highway over the access ramps. A second aspect was maintenance of traffic, which was a significant challenge given the heavy traffic volumes on the state highway. A third aspect was the design of the 40' x 80' station that had to comply with the then-new ADA specifications for handicapped accessibility. Platforms were needed as well as ramps between the platforms and the station. Landscaping also had to be addressed, including the preservation of certain forested and wetland areas. Finally, a construction timetable was prepared as well as a total cost estimate.

The presentations took place in the actual station. Because of this, the students were able to compare and contrast their design solutions with the ones that had been implemented. Moreover, since the KCI mentors were also present for the event, the students could ask questions about why certain design decisions had been made. In general, they discovered that the designs they developed were good; they could see striking similarities between what they had conceived and what had been built.

The students were also given certificates in recognition of their attendance at a graduation ceremony. A number of dignitaries from the state department of transportation, the local metropolitan planning organization, and the local transit authority attended and shared their perceptions of the retreat's value with the students.

Since 1998, Boston, MA has been the site for the Admiral Combs Design Retreats. In 1998, Frederic R. Harris was the host, and in 1999 through 2002, the host has been Parsons 
Brinckerhoff. The focus of these retreats has been the Central Artery/Tunnel project (the "Big Dig"). The general format is the same as it was in 1997, although with the Central Artery/Tunnel project, tours have become much more significant. Also, the students have worked on design tasks related to facilities that are under construction as opposed to ones that have already been built.

The typical retreat for the Big Dig project starts off briefing students with the overall project plans/designs, the construction stages and additional information about difficulties and experiences of the project. Students then travel into the field, viewing a variety of ongoing construction projects. The field trips have given the students a genuine appreciation of the scale of the Big Dig. Students then return to the office, where they are briefed on the task assignments and split into multi-disciplinary groups. The groups work on their design tasks and receive guidance from their professional counterparts (the lead engineer who was actually faced with the projects design problem). Students return to the field several times throughout the week, exploring sites crucial to their design tasks as well as sites that emphasize theoretical design that is seen in their courses. Finally, students present their design solutions to a large audience comprised of their classmates, participating faculty and professionals. In recognition of the efforts of all hard work that goes into the retreat each of the participants receive a certificate of participation.

Each of the five years, students have visited the slurry walls being built to hold back the earth and allow excavation of the cut-and-cover and tunnel freeway sections to be constructed beneath Atlantic Avenue. The students have also seen the jacking pits where tunnel sections are being fabricated to pass under the Amtrak/MBTA main line and the casting basin where concrete tunnel sections are being fabricated to pass under the Fort Point channel.

There were also some unique experiences associated which each retreat. In 1998, the students descended into the mining shafts that were constructed under Atlantic Avenue. They got to view the interior of what was to become a cast-in-place, post-tensioned concrete bridge, built completely underground to support the Red Line and allow northbound freeway lanes to pass underneath, more than 100 feet below the ground surface. In 1999, the students walked the length of the cut-and-cover tunnel sections under South Boston, seeing the way in which such facilities are designed, constructed, and finished. They also saw two more facilities: the large ventilation buildings for the Ted Williams tunnel and the south tower of the cable-stayed bridge being built across the Charles River. In 2000, the students toured the cable-stayed bridge being constructed over the Charles River. The towers and approach ramps were well under construction and much of the roadway was already in place. In 2001, students returned to the cable-stay bridge over the Charles River and got a first look at the traffic management center for the entire Central Artery/Tunnel Project. In 2002, students visited the cable-stay bridge (close to completion), walked the Fort Point Tunnel and toured an operating ventilation building.

The design tasks of the 1998 through 2000 retreats were focused on the I-90/I-93 interchange. For example in 1999, one group worked on an economic analysis of the tunneling options available for passing I-93 under (or across) the Fort Point Channel. Based on unit costs for various tunneling technology and other construction activities, their challenge was to determine

\footnotetext{
"Proceedings of the 2003 American Society for Engineering Education Annual Conference \& Exposition Copyright (C) 2003, American Society for Engineering Education"
} 
what tunneling technology or technologies should be employed to achieve a cost effective design. A second group prepared a layout for the I-90/I-93 interchange. Applying their traffic engineering skills, these students determined how the ramps and mainline freeway sections should be interlaced to accommodate all the various movements, while minimizing cost and producing the smallest possible disruption of both the commuter rail service and the Boston skyline. A third group worked on designing the support structure for vent buildings that sit atop the concrete tube sections passing under the Fort Point channel. Their structural engineering education was put to the test as they wrestled with issues of analysis, design, and material selection.

The design tasks of the 2001 and 2002 retreats focused on the cable-stayed bridge across the Charles River. For example in 2001, one group was challenged with designing a foundation for a typical I-93 viaduct bent. The study consisted of an evaluation, comparison, and selection of the optimum foundation system. A second group worked on noise mitigation and environmental impact analysis of the bridge construction. A third group worked on the structural design type study for a two ramp crossing of the Charles River, which carries traffic two, and from Storrow Drive (running parallel to the cable-stay bridge).

The past retreats proven to be successful in the eyes of all who were involved. The students have embraced the experience. The hosts enjoy the interactions and fresh ideas the students have to offer. The practicing engineers appreciate the interest of the future engineers and the faculty realizes the maturity the retreat offers the students.

\section{Understanding the Retreat's Value}

It is in the testimonies of those who participate and the regrets of those who do not that the value of the retreat becomes apparent. After participating in the retreat in 2000, one student stated, "If this doesn't encourage students to pursue civil engineering, I don't know what will” [26]. A participant in 1998 and current superintendent for a construction company in Washington, D.C., explains that, "the design retreat opened up my eyes to the construction aspect of civil engineering and really got me in tune with what type of projects and exciting advancements in the construction field are out there. This experience shaped my life personally, because now I'm working in the construction field" [34]. A participant in 1999 relates that at the Admiral Combs retreat, "you see all the different subdisciplines of civil engineering working to gether, and they are all essential for a complete project" [25].

Clearly, the event is worthwhile to all individuals involved, including students, practitioners, sponsors, and academics. The students like the bonding and exposure to real practice and practitioners. The practitioners like the retreat because it allows the students to see the relationship between the theory learned in school and the practice of the real world. The professionals also like the opportunity to mentor bright, young adults ready to enter the professional workforce. Alumni like the retreat because it brings back the strongest points of surveying camp, including both bonding and the promotion of the profession. Academics see its value as giving students a risk-free opportunity to experiment with creative solutions to complex problems, while encouraging teamwork, problem solving, leadership, and oral communication skills. 
One of the key arrangers for the retreats in Boston (a past contract manager for the Big Dig) thinks the retreat's foremost value lies in enhancing the students' understanding of the civil engineering profession [19]. It is his hope that the retreat will encourage them to pursue careers in construction and help to ease the shortage of talented people in that field. It also helps him to understand how young people need to be recruited, especially women and minorities. $\mathrm{He}$ encouraged his on-site staff to participate because they then had a chance to see how bright young students wrestle with complex design problems. The staff members remarked that they were most fascinated by the creativity of the solutions developed by the students.

A second chief person responsible for arranging the Boston retreats agrees that the retreat gives students a sense of civil engineering practice outside of the theory taught in the classroom [23]. It is a real-world environment, rather than a textbook example. The students get to see how the theory and analytical skills they learn in class pertain to real-world problems. They get to see how professional engineers accomplish their work. He values this event personally because it gives him a chance to give back to the next generation, encouraging them to do their part in improving civil engineering. For people like him, who are significantly detached from the academic environment, it is an opportunity to satisfy this personal need without creating a major disruption in his or her professional career.

Another person that is a strong supporter is an area construction manager on the Big Dig [12]. To him the main value of the retreat lies in its emphasis of exposing students to the real world of construction. He thinks this is especially true when a major urban infrastructure project is the setting, as with the Big Dig, with so many agencies and stakeholders involved.

A former chair of the Advisory Board for the Department of Civil Engineering at RPI argues that the retreat has allowed his firm to directly contribute to the development of future professionals [21]. Although he believes the retreat's biggest value is the bonding experience it provides for the students, he also esteems its focus on teamwork, presentation preparation, and multi-disciplinary problem solving by focusing on a real-world project. He thinks having the students work on solving the design problem first and then touring the actual facility is very positive. This was the template from the Maryland retreat. He perceives that for many students, this retreat is the first time they have seen the daily activities of a consulting engineering firm.

Another former chair of the Departmental Advisory Board says that when he tells his colleagues about the program, they respond with great interest and excitement [4]. As far as he can tell, there are not any other similar programs in existence. In fact, the practitioners and academics he speaks with think similar programs should exist elsewhere. All of these people agree that they would have attended such an event if it had been available at their school during their undergraduate career.

The Admiral Combs Design Retreat addresses all four of ASCE's main objectives: developing leadership, advancing technology, advocating lifelong learning, and promoting the civil engineering profession [1]. Through the retreat's team-building projects, students learn not only to lead but also to follow their peers. They learn how to work as a group, highlight the strengths of each team member, and focus on goal-oriented tasks. Multi-disciplinary teams now oversee all 
facets of the built infrastructure including planning, design, construction, operation, and rejuvenation. The teaching of leadership, teamwork, communication, and other interpersonal skills has become a requirement for all educational programs. Civil engineering students must learn how to be leaders in order for them to assume responsibility for major public works projects.

The design retreat also advances deployment of state-of-the-art design and construction technology by exposing students to best practice in both of these areas. In fact, in the case of the Boston retreats, much of this technology used on the Big Dig is new enough that the students would not have the opportunity to see it in a classroom.

Environmental stewardship is also something the students can see and experience. They see the environmental issues that have to be addressed in developing design solutions and they gain an appreciation for how environmental concerns affect the solutions that emerge.

Pursuit of advanced degrees is another objective indirectly supported by the retreat. The project leaders that the students see have advanced degrees and take pride in their continuing education. The students see how important it is to continue their education past a Bachelors degree. At the retreat, the students meet engineers that are experts in their field and most, if not all, have Masters degrees. The students realize that if they wish to work on the very best and most prestigious projects, a Masters degree is, in essence, a necessity. This also encourages another goal of lifelong learning. (This helps reinforce ASCE's call for the Masters degree to be the first professional degree [2].)

The students also meet role models that they can emulate. A major contributor to the Admiral Combs project points out that the retreat allows students to see successful RPI alumni practicing their profession [30]. It is particularly rewarding when the students decide that they want to follow a career in civil engineering.

By visiting the Big Dig, a \$13B project and the largest in US history, students also begin to understand the massive impact civil engineering decisions can have on such things as jobs, economic development, and societal well being. As Bordogna [5] says, "Engineers need to make the right decisions about how enormous amounts of time, money, and people are tasked toward a common end." A student, who participated in Admiral Combs as a student in 1998, remembers the "sheer enormity of the project, the incredible length of time, and number of people the project was consuming" [9]. Students also begin to understand the extent of the "invisible infrastructure" that supports society [5]. Hopefully, the subsurface infrastructure of Boston will never again be as exposed as it is now. This is a once-in-a-century opportunity to have future engineers understand the foundations and structures that they may someday need to repair.

One former participant, currently working professionally in highway design, also participated in the retreat as an advisor in 2000 [9]. He is a perfect illustration of Bordogna's desire to have industry "become more involved in the education of their current and future engineers" [5]. Dipalma states that, "From a professional standpoint, it was a great opportunity for me to network, and I have kept in contact with a number of people that I met the second time around. That was really valuable for me." He believes that, "In the job search, there's nothing better than 
a face-to-face meeting for a student or for a company" [9]. The design retreat gives companies a chance to interact with students; it allows them to talk to the students and to see them in action, designing and working as a team. Another former participant agrees that this retreat gives students a chance "to show potential employers what you can do under pressure, how well you work with a team, how well you adjust, and how well you digest something that's given to you" [25]. These characteristics are essential both to a position in civil engineering and to ideas that are difficult to accurately convey during interviews. The Admiral Combs Design Retreat allows firms to accurately know what to expect from students if they hire them. A participant from 2000 explained that after participating in the retreat, two firms involved offered to help her with her job search and place her in the city of her choice [32].

The host from Parsons Brinckerhoff agrees with the students [22]. He explains that from his perspective, the retreat allows his firm to establish a relationship with a first-rate university and a potential source of future employees. He believes it is important that corporations take an active role in the education process and appreciate that they have the opportunity to do so during the retreat. He and his colleagues also get to watch the students throughout the week. They watch them deal with specific problems, deadlines, and tasks that organize their thoughts to ultimately reach conclusions about a defined problem. In addition, Parsons Brinckerhoff gets the opportunity to tell students about their firm and potentially recruit new employees. The retreat also provides the project leaders with an opportunity to interface with undergraduates without having to take considerable time away from their day-to-day responsibilities.

The retreat is also an integrative event. Sack et al. [29] state that, "We must recognize the greater diversity in backgrounds, interests, and talents of entering engineering students and respond by exposing students to a wide range of topics." Civil engineering programs have a responsibility to help students find careers that not only bring them success, but job satisfaction as well. At Admiral Combs, students see every aspect of an engineering firm, from planning to design to project management. Students begin to realize that civil engineering is not one field; rather it is a combination of many different disciplines and careers all related to the common thread of the built environment. The diversity of professionals the students encounter at the Admiral Combs project not only demonstrates the number of career paths students can follow, but it also shows students that they will be working with people in all types of disciplines. A participant from 1997 explains that most students do not realize they will be working with people different from themselves [20]. "It helps you realize that you can work with people in other parts of civil, which I think happens a lot in the real world."

Another advantage of the retreat is that it gives a cohort of students from the same university an opportunity to get to know their classmates on a more personal level. At this retreat, bonding occurs in multiple settings. The most obvious is the teamwork required to meet the end-of-week deadline for a preliminary design on a complicated design task. A participant from 1998 says her team worked very hard [8]. "It really brought the civil engineering class together. You got to know your classmates." In addition, the students spend free time together. They rely on each other to get around and to find places to visit. Another former participant explains that, "You go to class with these people and you're really not immersed with everybody. But then you go out to dinner or ride the train and you can really learn what your classmates are about" [34]. An RPI

\footnotetext{
"Proceedings of the 2003 American Society for Engineering Education Annual Conference \& Exposition Copyright (C) 2003, American Society for Engineering Education ”
} 
alumnus and a major donor for the retreat, sees the retreat as a " modern surveying camp" [6]. That is, it accomplishes the many of the same goals that surveying camp did in a modern setting, giving students a way to practice their teamwork skills and to see how their classroom learning relates to the real world. It also lets them see the multidisciplinary nature of the profession. Furthermore, the retreat introduces students to role models, some of the profession's brightest and best practitioners.

This bonding makes the students' final year as undergraduates more successful in many ways. As one participant observed, "it was much easier to approach people in my classes" [32]. Another participant says she gained her first insights into networking during the retreat [8]. She said the retreat ensures "you have made good friends in your field before you're even in your field".

A past chair of the Departmental Advisory Board agrees that building interpersonal relationships are very important for professional success [4]. He himself values the friendships he forged with his classmates and hopes that Admiral Combs helps build these relationships for the Rensselaer students. He also hopes that the retreat shows them the strong personal interaction among senior staff at the host firms.

Team bonding also helps in the classroom. It is clear that the students who have participated in the retreat are much better prepared for the senior design class. They comprehend what design is about; they understand that design is open-ended and requires trade-off decisions. They know what they must do to succeed and they have a clear picture of what the end deliverables should be. Above all, they know how to get their fellow students to work together to achieve success.

\section{Conclusions and Prognosis}

The Admiral Combs Retreat is an effective, yet non-disruptive educational step towards a new civil engineering undergraduate curriculum. The program is neither disruptive to the participants, who need only to sacrifice a week out of their summer, nor to the professionals, who need not leave their workplace. No significant curriculum changes must be made for students to benefit from the experience at Admiral Combs.

Besides being non-disruptive, the retreat is in many ways risk-free. Because it is not-for-credit, students are free to follow their own wishes and make their own mistakes. Too often, students are penalized for trying an unconventional method that ends in failure. No attempt should end in failure, for every mistake is an educational tool. Nevertheless, the pull to follow the beaten path is strong when a grade is at stake. At the Admiral Combs Retreat, wild ideas are pursued and cherished for the educational steps involved. Educators can also use Admiral Combs as a way to test new material or teaching methods before using them in the classroom. The Admiral Combs retreat is innovative in every aspect, including its team-based learning strategies, which are tested and reviewed by the students involved.

At a more detailed level, the retreat's value appears to be derived from the following:

- It is extremely focused and well organized. The practitioners like the intense focus because it does not disrupt their schedules. The sponsors like it because it makes the

\footnotetext{
"Proceedings of the 2003 American Society for Engineering Education Annual Conference \& Exposition Copyright (C) 2003, American Society for Engineering Education"
} 
event financially supportable. The students like it because it does not disrupt their schedule, hinder their ability to get summer work, or interfere with their schoolwork.

- It is well scheduled. Holding the retreat just before the senior year starts creates a great segue between summertime activities and the upcoming fall semester. It is an exciting way for students to start their senior year.

- It is aimed at the appropriate students. After junior year, the students have enough technical skills to make this event meaningful.

- It is not compulsory. This means the students who partake in this event are very energetic and excited.

- It is not graded. As a result, the students can experiment with bold ideas and be creative without fear of failure or recourse.

- It has a limited number of attendees. At 10-25 participants, the number of students involved is both attractive because of one-on-one interaction and manageable, both financially and time-wise.

- The faculty involved is extremely dedicated to worthwhile learning activities and to the future success of their students.

In addition, holding the retreat at a landmark construction project, such as the "Big Dig", makes the retreat a truly unique experience. Few practicing civil engineers, let alone undergraduate students, ever get to see a project of such magnitude.

\section{Prospectus for the Future}

Rensselaer plans to advance and evolve this retreat in the years to come. One idea is to have miniretreats throughout the year. Another is to create similar experiences, perhaps smaller in scale, for students of every year, from freshman to graduate students. Rensselaer also has an objective of creating truly multi-disciplinary retreats involving architects, management majors, and other engineering majors. A final goal is to create multi-university or even multi-national events to expose students to different people and cultures.

Other civil engineering departments should follow suit. They need to find alumni willing to sponsor the event, firms interested in hosting the students, and windows during the year when the event can be scheduled. We encourage all universities to seriously consider creating such a retreat for their students. This is obviously not an easy task because three commitments must co-exist: funding, venue, and staff. As was said earlier, the cost for us has been about $\$ 10,000$ each year for groups of 8-18 students. It is possible to develop rational cost estimates that are twice that value. The staffing may be the most difficult challenge because it entails getting people to spend a week away from normal work to make it happen.

We also believe civil engineering firms should encourage and sponsor such events as part of their strategic alliances with schools from which they hire new employees. Even real estate development companies could sponsor such events to allow the students to explore ideas for new sites.

In closing, Rensselaer clearly perceives that this retreat has been a significant addition to its overall curriculum. The retreat will continue for many years to come. The authors encourage 
other programs to create similar retreats, tailored to their specific needs. And more generally, civil engineering educators should strive to add more hands-on experiences for undergraduate students so that better connections are forged between the knowledge gained in the classroom and the application of that knowledge to practical problems.

\section{Acknowledgements}

The authors would like to express deep thanks to the many people who made the preparation of this paper possible, as well as all of the past Admiral Lewis B. Combs Retreat participants. There are many students, practitioners, and sponsors who shared with us their insights about the retreat; students Beth Conzone, Janine Derjue, Chris DiPalma, Lisa Katcher, Cosmo Marifone, Margaret Tang, Brad Thompson; practitioners Paul Goguen, Jennifer Hill, Anthony Kane, Jack Kinstlinger, Tony Lancellotti, Mike Lewis; and alumni Howard Blitman, Dick Bouchard and Harry Schnabel. The opinions expressed are those of the authors. 


\section{REFERENCES}

[1] American Society of Civil Engineers (ASCE). (2000a). "ASCE Vision, Mission, and Goals." http://www.asce.org/aboutasce/vmg 060200.html.

[2] American Society of Civil Engineers (ASCE). (2000b). "First Professional Degree." http://www.asce.org/govnpub/policy/pol465 1profdegree.html.

[3] Bero, B.N., Zarow, L., Masayesva, V., Auberle, W.M. (1998). "Innovative NAU/EPA summer intern ship program." Proceedings of the Air \& Waste Management Association's Annual Meeting \& Exhibition, June 1418, 1998, 9pp.

[4] Blitman, H. (2001). Personal Communication, Rensselaer Polytechnic Institute, Troy, NY.

[5] Bordogna, J. (1999). “Tomorrow's Civil Systems Engineer - The Master Integrator." Journal of Professional Issues in Engineering Education and Practice, 124(2), 48-50.

[6] Bouchard, R. (2001). Personal Communication, Rensselaer Polytechnic Institute, Troy, NY.

[7] Bright, A. (1996). "Student, faculty and liaison roles in the Engineering Clinic program at Harvey Mudd College.” Proceedings - Frontiers in Education Conference, v3, November 69, 1996, Salt Lake City, UT, p 1449-1452.

[8] Conzone, E. (2001). Personal Communication, Rensselaer Polytechnic Institute, Troy, NY.

[9] DiPalma, C. (2001). Personal Communication, Rensselaer Polytechnic Institute, Troy, NY.

[10] Fiegel, G., and DeNatale, J. (1998). "Hands-on Geotechnical Engineering at the Undergraduate Level." ASEE Annual Conference Proceedings, June 28 to July 1, 1998, 8pp.

[11] Fink, L.D., Kolar, R.L., Muraleetharan, K.K., Nairn, R.W., Sabatini, D.A., Sack, R.L., Rhoads, T.R., Shirley, D.L. (2000). "Reengineering sooner civil engineering education." Proceedings - Frontiers in Education Conference, October 18-21, 2000, pp T1F-3 to T1F-8.

[12] Goguen, P. (2001). Personal Communication, Rensselaer Polytechnic Institute, Troy, NY.

[13] Gunn, C.J. (1998). "Focusing on the Needs of Engineering in Co-op." ASEE Annual Conference Proceedings, June 28 to July 1, 1998, 7pp.

[14] Hampton, D. (1999). "Inaugural Address.” 1999 Annual Conference and Exposition: Charlotte, NC. http://www.asce.org/aboutasce/99speeches_hampton.html.

[15] Hill, J. (2001). Personal Communication, Rensselaer Polytechnic Institute, Troy, NY.

[16] Huvard, G.S. (1998). "Make summer internship a learning experience." Chemical Engineering Education, $32(1), 48$.

[17] Illinois Institute of Technology (1999). "IIT charette." http://www.imiweb.org/imitoday/99 02/299p7-2.htm

[18] Johnson, A. (1997). "IE capstone design experience: From theory to practice." Proceedings - Frontiers in Education Conference, v2, November 5-8, 1997, Pittsburgh, PA, p 808.

[19] Kane, A. (2001). Personal Communication, Rensselaer Polytechnic Institute, Troy, NY. 
[20] Katcher, L. (2001). Personal Communication, Rensselaer Polytechnic Institute, Troy, NY.

[21] Kinstlinger, J. (2001). Personal Communication, Rensselaer Polytechnic Institute, Troy, NY.

[22] Lancellotti, T. (2001). Personal Communication, Rensselaer Polytechnic Institute, Troy, NY.

[23] Lewis, M. (2001). Personal Communication, Rensselaer Polytechnic Institute, Troy, NY.

[24] Liaw, B. (1995). "ECSEL's integrated approach to industry-academe relations." Proceedings - Frontiers in Education Conference, Part 1 of 2, November 1-4, 1995, Atlanta, GA, 12-15.

[25] Marifone, C. (2001). Personal Communication, Rensselaer Polytechnic Institute, Troy, NY.

[26] Mayr, E. (2001). Personal Communication, Rensselaer Polytechnic Institute, Troy, NY.

[27] Miller, M.H. (1998). "Industry internships as a tool for curriculum development." ASEE Annual Conference Proceedings, June 28 to July 1, 1998, Seattle, WA, 6pp.

[28] North Dakota State University (2000). "Ehly hall student design charette." http://www.ndsu.nodak.edu/arch/facilities/ehly/ehlycharette.htm

[29] Sack, R., Bras, R.L., Daniel, D.E., Hendrickson, C., Smith, K.A., and Levitan, H. (2000). "Reinventing Civil Engineering Education." Civil and Environmental Engineering New Millennium Colloquium, Massachusetts Institute of Technology, Cambridge, MA.

[30] Schnabel, H. (2001). Personal Communication, Rensselaer Polytechnic Institute, Troy, NY.

[31] Sener, J.C., Mirsky, R.R., Haws, D.R., Affleck, S.B., Mason, J.L., Aburusa, L.C. (1998). "Using web technology to promote student internship/cooperative education in College of Engineering at Boise State University.” ASEE Annual Conference Proceedings, June 28 to July 1, 1998, 15pp.

[32] Tang, M. (2001). Personal Communication, Rensselaer Polytechnic Institute, Troy, NY.

[33] Tener, R.K. (1996). "Industry-university partnerships for construction engineering education." Journal of Professional Issues in Engineering Education and Practice, 122(4), 156-162.

[34] Thompson, B. (2001). Personal Communication, Rensselaer Polytechnic Institute, Troy, NY.

[35] Van Ness, L. (1990). “Co-op. A vintage program for tomorrow's engineers.” Source: Engineering: Cornell Quarterly, 24 (3), 26-31.

[36] Varma, V.K. (1998). “Applying the rigors of internship principles to a successful co-op design.” ASEE Annual Conference Proceedings, June 28 to July 1, 1998, 6pp.

\section{Biographical Information}

GEORGE F. LIST : Dr. List is currently the Chair of the Department of Civil and Environmental Engineering at Rensselaer Polytechnic Institute and Director of the Center for Infrastructure and Transportation Studies. He is a graduate of Carnegie Mellon University (BSEE, 1971), the University of Delaware (MEE, 1976), and the University of Pennsylvania (Ph.D., CE, 1984). He is a past Vice-Chair and Secretary of the ASCE Department 
Session 3515

Heads Council Executive Committee.

STACY EISENMAN: Ms. Eisenman is a graduate of Rensselaer Polytechnic Institute (BSCE, 2002). She is currently pursing her M.S. in civil engineering at Rensselaer and plans to continue her education with a Ph.D. in transportation. She is a member of Tau Beta Pi and Chi Epsilon. Ms. Eisenman was a participant in the Admiral Combs Design Retreat in 2001 and an Assistant Director of the retreat in 2002. 